\title{
Transport Habits and Preferences of Generations - Does it Matter, Regarding the State of The Art?
}

\author{
Anita Kolnhofer-Derecskei, Regina Zs. Reicher, Ágnes \\ Szeghegyi
}

Óbuda University Keleti Faculty of Business and Management, Institute of Enterprise Management Tavaszmező u. 17, 1084 Budapest, Hungary derecskei.anita@kgk.uni-obuda.hu; reicher.regina@kgk.uni-obuda.hu; szeghegyi.agnes@kgk.uni-obuda.hu

\begin{abstract}
Every single day we spend one hour, on average, with travelling and this value has not changed for decades. According to the Hungarian timescale statistics, approximately one hour per day, on average, has been spent on travelling for the last 30 years. The world, however, has changed a lot in 30 years and one the best examples for this is the quick sequence of generations. Currently, there are at least four generations at the same time. The current study briefly introduces each generation, then discusses the differences and preferences in the travelling habits of generations who are present in the labor market. The aim of this study is to give a structured preliminary research plan, based on the state of the art. Therefore, the problems of further empirical research is reasoned and a well-structured research plan can be specified. Later, this conceptual model helps us to study and understand travel habits and preferences of various generations.
\end{abstract}

Keywords: travel habits; generations; preference; literature review; research plan

\section{Introduction}

According to the national travel timescale statistics, the time spent on travelling has not decreased since 1986/87, but the composition of the traffic has considerably changed and the distribution of travel time within society has also been irregular. [11] According to the 1986/87 timescale of KSH (Hungarian Central Statistical Office) we travelled 61.8 minutes per day on average; the survey indicated 59.4 minutes in 1999/2000 and 65.2 minutes in 2009/2010 spent on travelling. [10]

When we are talking about travelling, it is not equal to urban transport or commuting, it consists of more, because holiday trips and journeys should be also taken into account. Urban transport covers mostly, the public transport system in a 
city and commuting can be defined as "travelling from home to the workplace" [8]. For example, a business trip happens out of the city, but the aim differs. In this paper everyday travelling choices were examined regarding the secondary data, therefore, all expressions were used as similar. Several things can affect the time spent on travelling: demographic background of users; typical features of the given settlement or the social status. [22] Fleischer and Tir [10] analyzed the six explanatory variables together (age, gender, activity, qualification, county, and settlement-category) and they found that it could be explained only through $10 \%$ of the heterogeneity of the time-use values. It was the age and the activity status that influenced the time-use pattern best. Therefore, our travels can be influenced by several factors; the present study will focus on the differences by age. The age is examined from two aspects: (1) generation characteristics and (2) age characteristics. Fleischer and Tir [11] analyzed the Hungarian data and reached the conclusion that during the sixty-year period from the age of 20 to the age of 79 the time spent on travel is decreasing by one minute by approximately one ageyear, from about 90 minutes to 30 minutes. (Fig. 1)

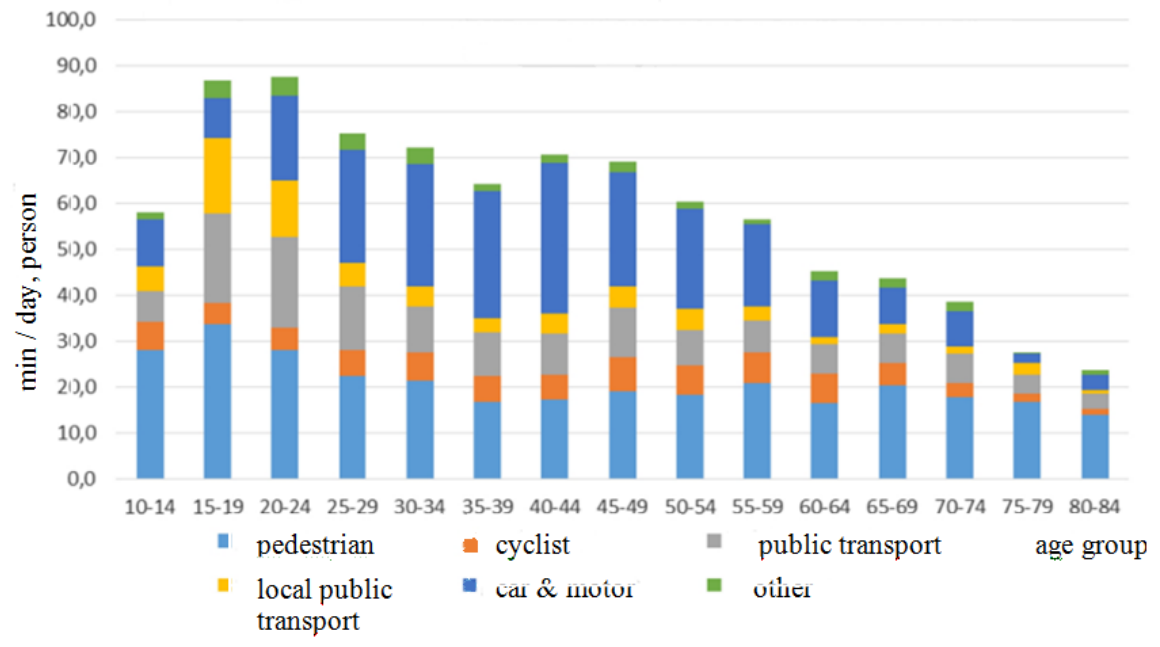

Figure 1

Time spent with travel (minute/day, head) in the population aged 18-84 according to age groups and modes of travel, 2009/2010 [10]

Examining the chosen means of travel (how the referred authors called them), the most striking difference can be observed in case of car and motorbike travel. While men aged 40-44 would spend 43.5 minutes per day on average in a car (it is 21.6 minutes in case of women); it is reduced to 18.2 minutes for 60-64 year old men (and 7.6 minutes for women of the same age group). This can also be explained by the commuting to work, because the working-age starts after schoolleaving age and lasts until retirement. Although mobility and willingness to travel has increased, the objective of everyday travel is still commuting to work [13]. 
Travelling to work is the greatest item for the employees on weekdays. Therefore, the time-use within the work week is different on work-days and weekdays. Although daily commuting and long travels are decreasing the free time in case of each generation, but there are some activities, where this condition does not apply. Moreover, among those aged 17-29, the daily commuters spend even more time with social leisure activities than their non-commuter fellows, who work where they live [23]. The daily commuters make up for the time lost during weekdays on the weekends and they spend more time with looking after their children over the weekend than those working near their residences. The travel destinations in the weekends include shopping centers, visits to family and friend, as well as doing sports or engaging in cultural activities. [23] Regarding travel destinations, there is a huge difference between travelling on weekdays and during a weekend.

The travel habits, of course, can be characterized not only by the time spent on it but also by the chosen means of transport and this latter is justified by the travel distance. Regarding public transport and considering the number of passengers carried in the domestic long-distance passenger transport, the share of bus traffic was dominant (77\% in 2017) and the share of rail passenger traffic was $23 \%$. In international passenger transport, $49 \%$ of passengers travelled by air, $32 \%$ by rail and $20 \%$ by bus. The public transport within a settlement meant bus transport (55\% is the share of passengers carried); streetcar (22.7\%), tube and underground (14.5\%), trolleybus (4.8\%) and HÉV Suburban Railway Service (3\%). $40 \%$ of travels considered without returning home was commuting. Regarding the means and methods of transport, $27 \%$ of passengers named public transport on a national level; $38 \%$ travelled by car and $17 \%$ travelled by bicycle. [15]

In terms of individual travel, the sharing of cars is still a strongly determinant factor and this tendency is even growing. Parallel with this, the number of automobiles registered for the first time in Hungary is increasing year by year. [21] (Fig. 2) It does not mean that the car use is also exponentially increasing at this pace; it is much more that travelling by car has become part of a mixed, modal travelling lifestyle; in other words, the passenger is changing the means of transport flexibly. Together with this, parking has also become an issue in all of the dense population areas. The European Union drafted an action plan to solve parking issues several years ago and researchers have been working on multiple, real-time information systems, in order to find a solution for this expanding and urgent problem. [28] Owning a car, however, still has a strong impact.

According to a representative survey carried out in 2016 in Hungary, 44\% of households had at least one car. Out of them $39 \%$ owned one car, while $5 \%$ of the households had two or more vehicles [9]. On the basis of statistics, the individual transport - with all its advantages, disadvantages and risks - has become the main method of mobility besides public transport. The authors explain this with suburbanization processes, spread of corporate cars and the cost efficiency, because some would say „if we have a car, only the fuel means extra cost when we travel". [13, p. 187] 


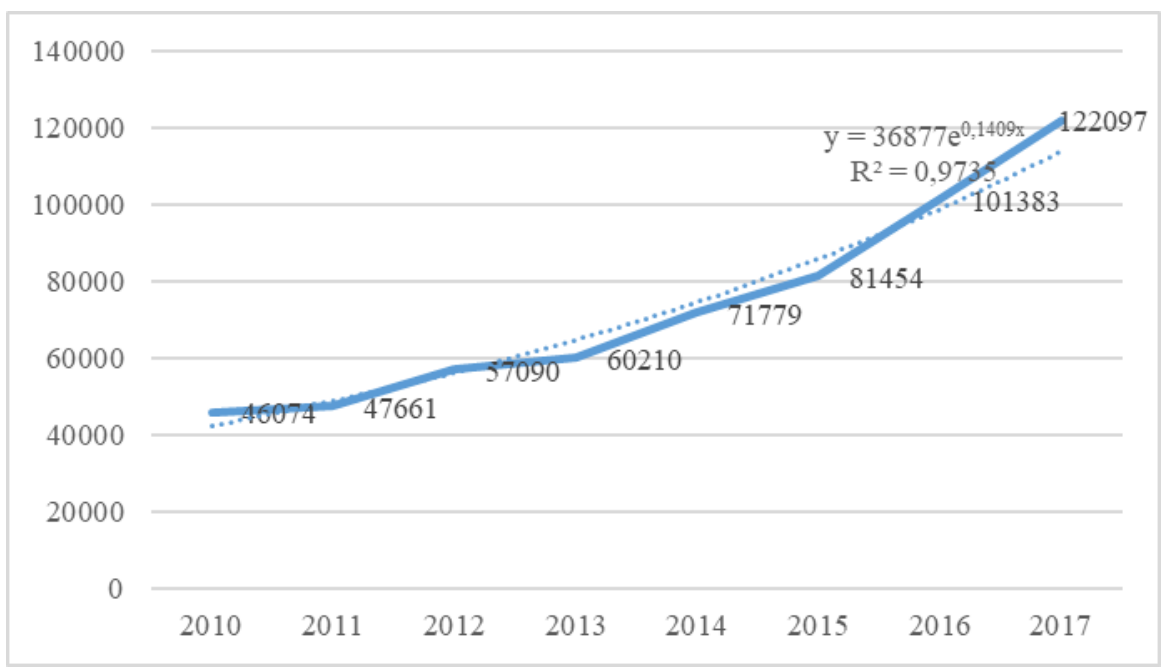

Figure 2

Number of road vehicles per year registered for the first time in Hungary (pcs.) (Source: [21])

And the fuel prices have increased proportionally to a lesser degree than the public transport tickets, the price of which grew 64-fold between 1990 and 2013, although this feeling is changing over time. The data of the Hungarian Central Statistical Office from 2013 contradict to this statement: the Hungarian population spent 732 billion HUF on transport in 2012; $71 \%$ of this amount (519 billion HUF) was spent on car use including motorway and parking fees but excluding taxes, insurance costs and costs of car purchase. 212 billion HUF was spent on public transport. Comparing these values with the distance taken by the individual means of transport, it can be concluded that the cost of car use $(25 \mathrm{HUF} /$ passenger kilometer) is significantly higher than the average cost of public transport (15 $\mathrm{HUF}$ /passenger kilometer). But car owners and car users must be separated also. Regarding the different ages of the drivers and passengers, the younger and elder generations belong to the second part. In case of car use there is another wider issue to be considered, namely the state and length of local and national road network. This was almost 207 thousand kilometers in 2016, and it had not changed significantly compared to 2010. Since 2010, the length of bike paths and motorways has grown the most (by 56\% and 44\% respectively), while the length of roads belonging to the category of other types of roads and the length of footpaths has decreased (by $1.4 \%$ and $1.0 \%$ respectively). The length of motorways in $2016(1168 \mathrm{~km})$ was more than in 2010 by $9.5 \%$. [16]

The expenditures of households spent on transport are also affected by the type of the settlement. While on average $20 \%$ of Hungarian households spend only on means of public transport, this ratio is $29 \%$ among the households in Budapest. Only $17 \%$ of the citizens in the capital city spent money on cars as opposed to the 
average Hungarian ratio, which was $28 \%$. This, of course, did not mean that less people had cars; it rather referred to the mixed transport (while $25 \%$ of the Hungarian households spent on public transport as well as car use, this ratio is $30 \%$ in Budapest). [15]

HUF 8984 per head and per month was spent on travelling and transport in 2018 on average; the greatest proportion of which was fuel purchase, with HUF 6209 per month. This type of expenditure increased by $6.4 \%$ on current prices compared to the previous year. [21] The cost of travel and transport is the third largest item in the monthly expenditures of households; it was $10.8 \%$ of total consumption expenditure. Compared to year 2000 (volume index, year $2000=$ $100 \%$ ) the volume change of consumption expenditures of households was $180.8 \%$ in terms of travel costs; regarding the structure of consumption expenditure per head it was $11.5 \%$ in the households. [18] Regarding this value, however, there has been a gradual decline because the ratio of money spent on travelling has been gradually decreasing in the household consumptions. In the first half of 2017 the average spending per head was HUF 8928 per month. [19]

Regarding the bicycle usage that is for local public transport, it is used first of all by those living in smaller towns or villages, where there is access to local transport. An average Budapest resident spends 27 minutes on this mode daily, 45 times more than the capacity of a village or small town resident to avail of this mode. Contrarily, in case of long distance public transport, village residents spend almost three times more time on this mode than the residents of Budapest or of the county centers do. [10] Although there are more and more cyclists in the capital city as well and the bicycle sharing system (MolBubi) is also growing, the present study does not further discuss this means of transport.

In this chapter we try to organize all those factors which influence travel and commute habits. Fleischer and Tir [10] provided a multidimensional model which characterized two secondary important factors. The first was the effects of different demographic, social backgrounds on the transport time-use variability. The second was the specialties in the time-use character of the different transport modes. Regarding the first one they found that the social background (i.e. six explanatory variables together like age, gender, activity, qualification, county, and settlement-category) explained only $10 \%$ of the heterogeneity of the time-use values. The age and the activity status influenced the time-use pattern best. As for the age groups: between age 20 and 80 years the average daily transport time use decreased from 90 minutes to 30 minutes. Looking at the activity, $60 \%$ of the time-use of the population is produced by the $51.7 \%$ employed people. 


\section{Generations}

Despite of the fact that age and activity influence transport and commute preferences, the passengers are not divided into separate age groups in the available Hungarian statistics, even though the international references extensively discuss the comparison of travel habits and preferences by generations. The definition of generation according to the glossary of definitions by the Hungarian Central Statistical Office (KSH) says that generation is a specific type of population cohort: it means a group of people who were born in the same year. As the members of a generation should live through demographically important events (for example getting a degree, marriage, birth, employment, death etc.) interlocked this way time and frequency of occurrence of these events are comparable with factors affecting in time. In other words, the impact of social and historical background, in which the given generation is growing up, is significant, but all the generations go through the same stages of life and more or less they have to face the same challenges during this journey.

As it was discussed above, the working age population travels the most. Currently, there are three generations on the labor market at the same time. The generational differences are markedly visible in the field of HR. [25]

Our previous work discussed the HR relevant differences among generations in detail [14] and their travelling habits were also briefly reviewed. [26] Table 1 below provides a summary of the latest composition of the national labor market on the basis of the Hungarian Central Statistical Office (KSH) database, as well as references and own research outcomes.

In case of individual generations, that historical, social and cultural background should be highlighted, in which the members of the generation of the given age (cohorts) were raised. In other words, the changes of the world generate the generations. The borderlines between generations are not nearly as sharp; it is also proven by the existence of the so-called intermediate (cuspars) generation. In addition to this, the individual birth years may differ by regions and countries; moreover, each generation can be further divided by life stages. Let's just consider that the younger members of $\mathrm{Y}$ generation still live with their parents and study, while the older members work and some of them even founded a family or at least leads an independent household apart from their parents. Hereinafter, several examples prove the above by analyzing international professional literature sources. The biggest emphasis in research is given to the $\mathrm{Y}$ generation or Millennials. "Millennials are also living through times of economic dislocation and technological change. History shows that the combination of technological change, such as the advent of smartphone technology, television, or radio; combined with macro forces that shape behaviors, such as the Great Recession, the Great Depression, or World War II can lead to societal change that can last generations. 
Table 1

Description of individual generations

\begin{tabular}{|c|c|c|c|c|c|c|}
\hline 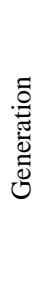 & $\begin{array}{l}\text { Ẽ } \\
0 \\
0 \\
0 \\
0 \\
0 \\
0\end{array}$ & $\begin{array}{c}\text { Short description } \\
{[3]}\end{array}$ & $\begin{array}{l}\text { Historical background } \\
\text { they were raised in }\end{array}$ & 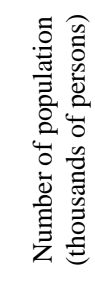 & 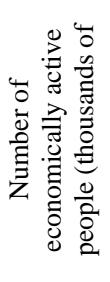 & 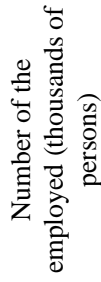 \\
\hline 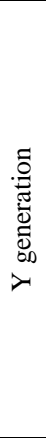 & 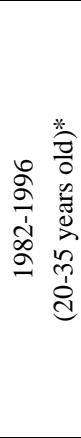 & $\begin{array}{l}\text { delay in marriage, } \\
\text { childbearing and other } \\
\text { life events } \\
\text { high adoption of } \\
\text { technology } \\
\text { credited to have higher } \\
\text { preference for urban } \\
\text { areas } \\
\text { delay in driver's } \\
\text { licensing compared to } \\
\text { previous generation }\end{array}$ & $\begin{array}{l}\text { global economic crisis; } \\
\text { strong globalization; free } \\
\text { movement } \\
\text { mobile and smart devices } \\
\text { and applications; Internet } \\
\text { is part of everyday life; } \\
\text { greater mobility } \\
\text { (mobility-encouraging } \\
\text { services, e.g. Erasmus } \\
\text { program or products e.g. } \\
\text { low-cost flights); } \\
\text { Influencers and bucket } \\
\text { list. }\end{array}$ & 1769.6 & 1296.6 & 1224.2 \\
\hline 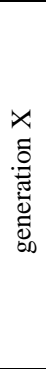 & 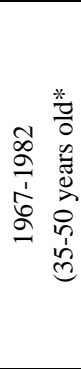 & $\begin{array}{l}\text { active workers } \\
\text { often live with children } \\
\text { telecommute more often } \\
\text { increased adoption of e- } \\
\text { commerce }\end{array}$ & $\begin{array}{l}\text { change of regime; } \\
\text { Western impact, } \\
\text { globalization (less } \\
\text { obstacles in front of } \\
\text { travels, transition to EU); } \\
\text { new technologies, } \\
\text { personal computers, } \\
\text { mobile devices, world } \\
\text { wide web, travel } \\
\text { magazines, exhibitions, } \\
\text { programs. }\end{array}$ & 2254.6 & 2013.3 & 1946.9 \\
\hline 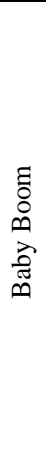 & 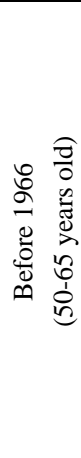 & $\begin{array}{l}\text { transitioning into } \\
\text { retirement } \\
\text { higher income generation } \\
(* \text { not in Hungary) } \\
\text { increased amount of } \\
\text { discretionary funds for } \\
\text { leisure trips } \\
\text { less need for space in } \\
\text { residential location }\end{array}$ & $\begin{array}{l}\text { socialist era, closed } \\
\text { economy; no chance or } \\
\text { only limited and strictly } \\
\text { restricted chance for } \\
\text { travel, e.g. strong } \\
\text { customs, currency limit) } \\
\text { landline phones, radio } \\
\text { and television; written } \\
\text { communication (through } \\
\text { mail); stores for } \\
\text { purchases in foreign } \\
\text { currency, exclusive } \\
\text { foreign goods, dissident } \\
\text { acquaintances. }\end{array}$ & 1910 & 1220.9 & 1176.4 \\
\hline
\end{tabular}

*Age is adapted to the data of KSH classification (year 2017); year of birth is according to the references 
It is in this context that Millennials, with their relative propensity for urban lifestyle components (whether they live in cities or in suburbs), dexterity with technology, while starting careers during economically constrained times can leave a lasting impact on society. In fact, they are already driving trends." [1]

It is very interesting that in the field of age grouping, the KSH (Hungarian Central Statistical Office) only classifies by generations in one study (different years of birth were indicated in the classification). This study analyzed the internet use habits. It means that the description of individual generations can be closely related to the technological changes. Currently the internet use is part of a modern lifestyle in Hungary; according to the KSH [20] 69.9\% of respondents connects to the Internet every day, while $20 \%$, several times per week. When they are asked what they generally think about Internet, $56.9 \%$ of the population declared that they regard it indispensable and only $20 \%$ say that they could live happily without it. Primarily, the members of generation $\mathrm{Z}$ are web connected and feel it is indispensable $(83.7 \%)$ while older people, the members of the baby boom generation, could tolerate the absence of internet with less trouble. Therefore, the generations we examined can be distinguished on the basis of their relation to IT and the World Wide Web. This paper shows that internet use habits are related to generational differences, because this factor differs slightly among each generation, and influences their behavior, even though, this factor must be taken in consideration.

The "online" generation would like to be connected and in real-time, anywhere and anytime. For this, they need appropriate IT support and the use of both their hands; therefore, they cannot split their attention to driving a car. This need is also obvious in the purchase of transport services. In addition to comfort and cost efficiency, the environmental consciousness further strongly justifies the preference of new (mixed and public) means of transport. Csigéné et al. have confirmed this in their study on a Hungarian sample. Their conclusions show the interests of Millennials on sustainable consumption and eco-labeling. [7]

\section{International Results}

Although there have not been any Hungarian studies in transport and commuting research dealing exclusively with generation differences; International Professional sources in English, refer to this topic several times. Unfortunately, the targeted topic (i.e. generational differences regarding transport habits) was not studied, typically the age differences were underlined, but mostly these sources were from the characteristics of the labor market (e.g. commuting as a part of transport). This study focuses on the generational differences. The latest most relevant study was examined by Circella et al. - prominent representatives of the topic - have been doing one of the most extensive researches [5]. They studied Millennials' choices, through the analysis of a comprehensive secondary dataset 
and approximately 2400 residents of California, including both Millennials and members of Generation X.

They have concluded that Millennials are increasingly reported to behave, and travel, differently from previous generations at the same stage in life. Among the observed changes, they postpone the time they obtain a driver's license, often live in urban locations and do not own a car, drive less if they own one, and use alternative travel modes more often. Millennials' current choices are expected to be a sum of lifecycle, period and generational effects: their current behaviors are not necessarily going to continue as Millennials grow older and transition to more stable life stages. Millennials tend to live in areas that have the lowest levels of accessibility by non-car modes. This sharply contrasts the residential location of independent Millennials who are more often found to live in locations with higher accessibility. Central locations are more conducive to the adoption of greener and non-auto commute modes (and/or may reinforce the propensity of young adults to use such modes or to adopt multimodal travel). In addition to this [2] the Generation Y cohort generally have lower rates of driver licensing, vehicle registration and car ownership, in addition to their increased rates of public transport usage. These trends have been observed in many countries around the world, including the USA, Australia, Canada, Japan, the UK and many other European counties.

Urban mobility literature has also been reviewed and processed by Cost et al. [6] According to their conclusions, generation $\mathrm{Y}$ twice as willing to ride a bicycle than the older generation; three times as willing to choose shared transport (e.g. Uber) and five times is happier to use public transport to commute to school or to work. Gen X'ers rely heavily on the use of cars for their commute. Many older Millennials who live in urban areas actually report that they do plan to purchase a new vehicle in the near future, but they are less likely to be mono-drivers and more likely to be multimodal commuters, even if they live in neighborhoods that are less supportive of such behaviors. Millennials often report reducing their use of transit 15 or the amount of walking or biking as the result of the use of Uber/Lyft or other shared mobility solutions that mean of travel is not straightforward.

Lavieri et al. [24] examined the driver's license holding, vehicle ownership, and commute mode choice of the millennial generation. According to their results, parenthood is associated with an increase in driver's license holding and personal vehicle ownership; Parents are likely to express a greater pro-car attitude than non-parents, a finding that is consistent with expectations. Parents need the flexibility afforded by a personal automobile to transport their children, in addition to fulfilling their own travel needs and hence, vehicle ownership is higher in households with children. Through these mixed-use developments, where Millennials can work, play, and shop within short distances could help foster the continued use of non-motorized modes of transportation. Moreover, Millennials who are more technology-dependent exhibit lower levels of vehicle ownership and 
usage, and higher levels of non-motorized mode and transit use for commuting. [24]. Now, associates of these young people are using transit more than in past years. [12] Millennials are multimodal; they choose the best transportation mode (driving, transit, bike or walking) based on the trip they are planning to take. [1] Public transportation options are considered the best for digital socializing and among the most likely to connect the user with their communities. Transit also allows Millennials to work as they travel. They justify their choices by clear competitive advantage. Reasons and motivations for transportation choices are pragmatic, with $46 \%$ stating that a need to save money drives their choices; $46 \%$ note convenience, $44 \%$ want exercise and $35 \%$ say they live in a community where it just makes more sense to use other transit.

Shearmur [29] divides the members of generation Y according to their travelling habits. The individual groups travel depending on their labor market situation and occupation because work can be performed across the city, on the move or on the fly. The three groups are as follows: (1) hyper-mobile knowledge-related jobs independent artist, or a successful businessperson who prefer a wide variety of urban locations (2) semi-mobile: dog walkers, hairstylists who come to clients' homes, house cleaners - these occupations have no fixed place-of-work, and do not have the same locational freedom (3) and ordinary fixed place-of-work. [29]

We have found an interesting research in the studies of Bösehans and Walker, who specifically concentrated on bus transport and identified different types of bus users. In this sample, $88 \%$ of bus users lived within a four mile radius of the university campus, supporting the notion that bus trips can be sufficiently short to be undertaken by either walking or cycling. [2]

Further research has been done in Great Montreal [12] and New Zealand with focus group depth interviews and online surveys. [27] The conclusions are very similar. It seems that the changing generations and the new habits and attitudes have an impact on transportation as well.

\section{Research Plan}

\subsection{Research Questions}

Based on the aforementioned facts, we would like to describe our research plan. We are interested in the demographical impacts (highlighted the age) on transport and commute habits. First, the methodological facts are listed: (1) mostly preferred and used method is diary technique, with it, a longer time period can be studied, providing a possibility to compare weekday and weekend activities. In addition this method results in qualitative and quantitative data. The Hungarian 
The age-related and generational impact definitely showed up in the transport habits and preferences that we examined. Fig. 3 compares this tendency, which has also been discussed in international references [3] and our own preliminary hypothesis.

In sum, we would like to study the following topics and areas: transport habits and preferences among different Hungarian generations' members. We focus on the following three generations (1) Baby Boomers (2) generation X (3) Millennials or Gen Y. Finally the Fig. 4 shows a possible conceptual model about the measurewanted factors.

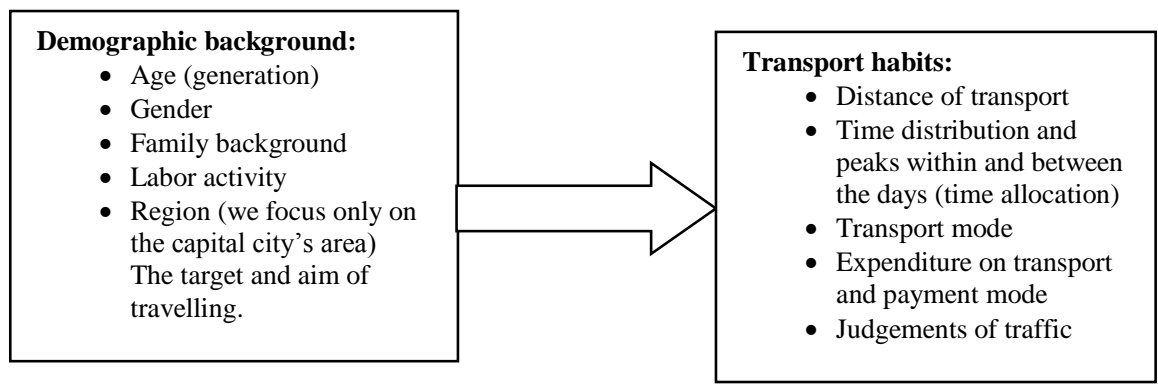

Figure 4

Conceptual model of further research

Although the demographic background is an important influencer, we focus only on age factor, using generation scales, because different generations are used to and socialize in different life environments. At the same time each generation goes through the same life periods. We are interested in the impact of the generational differences. Focusing on this, the following factors could be foreseen as influencers: (1) time spend and distance traveling (2) peaks in time distributions like (a) travels during certain times of days in a week and (b) travel times in one particular day (3) feeling and judgment (experiences) of the traffic (4) expenditures (a) amount of expenditure and (b) mode of payment (5) last, but not least, the preferred mode of transport.

Our preliminary hypothesis can be the following:

H1. Age (grouped into generations) will influence users commute and transport habits.

Here we anticipate the impact from factor (1) to factor (4), because these factors are determined by the aim and target of travelling.

H2. Life period and labor activity have a stronger impact on preferred transport mode.

Here we anticipate the impact of factor (5) which has an indirect impact on H1. 
This last factor is the most interesting, we are interested in quantitative and qualitative data, as well, because reasons and ways of thinking given by the various generations' members, are meaningful and useful.

\section{Conclusions}

Understanding the differences among generations would take us closer to the planning of a future means of transport. The working-age population travels the most, but this population cannot be regarded as homogenous. The KSH analysis made on a Hungarian sample highlighted this fact [23], saying that "the proportion of commuters is significantly higher among employed men, youth, people with lower school qualifications and those living in villages, than those among women, older people, people with higher school qualifications and those living in towns." The characteristics of daily travel, however, are not uniform; there are considerable differences by the size of settlements, social, economic and demographic features, seasons, days of the week, time of the day, aim of travel or the chosen means of transport. For example, people living in Budapest use public transport as opposed to a car, in significantly higher proportion than the national average. [15]

As Circella et al. saw the new generation [5], Millennials are in a "changing" stage of their lifecycle, in which they are building the basis for their future life, family and work career. They will contribute to create new households and influence future travel patterns in many ways. Millennials are more technologically oriented than their older peers. They use social network platforms, internet and smartphone apps more often to perform certain activities and engage more often in travel multitasking. They show a stronger commitment to protecting the environment and are less opposed to increases in gas taxes to provide funding for public transportation [4].

Although the impact of generation characteristics is not negligible, the impact of age specific features is much stronger. Moreover, the two go hand in hand. It is clear that the typical age characteristics, in the case of generations, are shifted. The daily time scale also indicates the shifted life stages; as discussed by Lakatos [23]: "women give birth to their children at an increasingly older age, thus the 1729-year-old people spend only 17 minutes per day on average on looking after their children, while the 30-49-year-old people spend twice as much, 33 minutes.

After all this, the question is: what affects the mobility of generation Y? The answer surveyed on an American sample [3], can be summarized as follows, in Table 2.

In summary, it can be concluded that the generational differences can be observed, but the age characteristics or the geographical demographic features have a much stronger impact on whether this trend is temporary, sustained or growing. Lavieri et al. has reached the same conclusion: Millennials seem to become more autooriented as they age and gain economic resources. [24] 
Table 2

Factors affecting the travel preferences of generation Y [3]

\begin{tabular}{|c|c|c|c|}
\hline $\begin{array}{c}\text { Economic } \\
\text { Recession } \\
\text { Unemployment }\end{array}$ & $\begin{array}{c}\text { Auto cost } \\
\text { Gasoline } \\
\text { Auto insurance } \\
\text { Auto repairs } \\
\text { Driver's education } \\
\text { Other fees }\end{array}$ & $\begin{array}{c}\text { Technology } \\
\text { Communication } \\
\text { technology } \\
\text { Transportation } \\
\text { technology (Uber) }\end{array}$ & $\begin{array}{c}\text { Demographic } \\
\text { Changes } \\
\text { Delayed marriage } \\
\text { Fewer children } \\
\text { Boomerang effect }\end{array}$ \\
$\begin{array}{c}\underline{\text { Residential }} \\
\begin{array}{c}\text { Location } \\
\text { move likely to and live } \\
\text { in cities }\end{array}\end{array}$ & $\begin{array}{c}\text { Environmentalists } \\
\text { Less materialistic }\end{array}$ & $\begin{array}{c}\text { Regulatory } \\
\text { Graduated driver's } \\
\text { licensing } \\
\text { Texting while } \\
\text { driving laws }\end{array}$ & $\begin{array}{c}\text { Alternative Modes } \\
\text { infrastructure for } \\
\text { walking, biking } \\
\text { Sharing commute }\end{array}$ \\
\hline
\end{tabular}

The aim of this study is to draft further empirical, primary research, which enables the testing of our preliminary hypothesis but; the limitation of our study should also be mentioned. In case of the above classified high number of secondary data, the different generation limits, the limits given for the members of individual generations in the year of their birth may cause problems. Although it is understandable, because the classification limits (due to the definition) refer to the given social cultural impacts.

\section{Acknowledgement}

Supported By the ÚNKP-17-4/I. New National Excellence Program of the Ministry of Human Capacities. The research was carried out in the frames of BrainBayCentrum.

\section{References}

[1] Association, A. P. T., 2015. Millennials and Mobility. [https://www.apta.com/resources/reportsandpublications/Documents/APTA -Millennials-and-Mobility.pdf, downloaded 10/06/2018]

[2] Bösehans, G. \& Walker, I., N. D. 2016. 'Daily Drags' and 'Wannabe Walkers' - Identifying dissatisfied public transport users who might travel more actively and sustainably. Journal of Transport \& Health, Volume 3, Issue 3, pp. 395-403

[3] Circella, G., 2015. FACTORS AFFECTING PASSENGER TRAVEL DEMAND IN THE UNITED STATES, California: Planning Horizons Seminar. White Paper Draft. [http://www.dot.ca.gov/hq/tpp/offices/owd/horizons_files/NCST_WP_Trav el_Demand_Draft.pdf, downloaded 10/06/2018]

[4] Circella, G., 2017. What Affects Millennials' Mobility? PART II: The Impact of Residential Location, Individual Preferences and Lifestyles on 
Young Adults' Travel Behavior in California, California: National Center for Sustainable Transportation (NCST). Research Report. [https://steps.ucdavis.edu/wp-content/uploads/2017/10/CIERCELLAFULTOIN-PART-2-2017-UCD-ITS-RR-17-05-2.pdf, downloaded $10 / 06 / 2018]$

[5] Circella, G. \& Berliner, R. \& Lee, Y. \& Handy, S., L. \& Alemi, F. \& Tiedeman, K. \& Fulton, L. \& Mokhtarian, P., L. 2017. The Multimodal Behavior of Millennials: Exploring Differences in Travel Choices between Young Adults and Gen Xers in California

[6] Costa, P. B., Morais Neto, G. C. \& Bertoldec, A. I., 2017. URBAN MOBILITY INDEXES: A BRIEF REVIEW OF THE LITERATURE. Transportation Research Procedia, pp. 3645-3655

[7] Csigéné, N. \& N., Görög, G., \& Harazin, P. \& Baranyi, P. R., 2015. „FUTURE GENERATIONS“AND SUSTAINABLE CONSUMPTION. Economics and Sociology, Vol. 8, No. 4, pp. 207-224

[8] Davis, D. \& Dutzik, T., 2012. Transportation and the New Generation. Why Young People Are Driving Less and What It Means for Transportation Policy, USA: Frontier Group

[9] Ficzere, F., 2016. Bosch a magyar autóhasználati szokásokról. / Bosch about the Hungarian Car Usage Habits. http://www.aoeportal.hu/index.php/infokozpont/hirek/365-bosch-kutatas-agepkocsik-eletkora-atlagosan-11-ev-magyarorszagon [online, downloaded on $06 / 2018$ ]

[10] Fleischer, T. \& Tir, M., 2016. The transport in our time-budget. Regional Statistics, pp. 54-94

[11] Fleischer, T. \& Tir, M., 2018. Hazai közlekedési idömérleg elemzés. / Domestic transport Time Use Research. Siófok, Budapesti és Pest Megyei Mérnöki Kamara, pp. 81-86

[12] Grimsrud, M. \& El-Geneidy, A., 2014. Transit to eternal youth: lifecycle and generational trends in Greater Montreal public transport mode share. Transportation, 41. pp. 1-19

[13] Kiss, P. J. \& Szalkai, G., 2018 58(2). Az ingázás mobilitási jellemzői a legutóbbi népszámlálások adatai alapján. / Commute characteristics based on the census. Területi Statisztika, pp. 177-199

[14] Kolnhofer Derecskei, A., Reicher, R. \& Szeghegyi, Á., 2017. The X and Y Generations' Characteristics Comparison. Acta Polytechnica Hungarica, pp. Vol. 14, No. 8, 107-125

[15] KSH, 2013. June 27. A lakossági közösségi és egyéni közlekedési jellemzői. / Public and individual transports' description. 2012. Statisztikai Tükör, VII. 47 
[16] KSH, 2016a. A települések infrastrukturális ellátottsága. / Settlement’s infrastructure. 2016. Statisztikai Tükör

[17] KSH, 2016b. Az ingázás kiemelt célpontjai. / Accentuated Target of transport. Budapest: Központi Statisztikai Hivatal

[18] KSH, 2017a. A háztartások fogyasztása. / Domestic household consumptions. 2017. I. (preliminary data). KSH

[19] KSH, 2017b. Kiadási radar adatok. / Expenditures radar data. Budapest: Központi Statisztikai Hivatal

[20] KSH, 2018a. A háztartások fogyasztása, 2017 (elözetes adatok). / Domestic household consumptions. 2017 (preliminary data) Statisztikai Tükör

[21] KSH, 2018b. Szállítási teljesítmények, közúti közlekedési balesetek. I Transport records, Transport Accidents on Public roads. 2018. I. quarter. Statisztikai Tükör

[22] Kukely, G. \& Aba, A. \& Fleischer, T., 2017. New framework for monitoring urban mobility in European cities. Transportation Research Procedia, pp. 155-162

[23] Lakatos, M., 2013. A foglalkoztatottak időfelhasználása az ingázás és a munkába járás idejének tükrében. /Employers' time use depending on commutes to the workplaces. Budapest: KSH Mühelytanulmányok 13

[24] Lavieri, P. S. \& Garikapati, V. M. \& Bhat, C. R. \& Pendyala, R. M., 2017. An Investigation of Heterogenity in Vehicle Ownership and Usage for the Millennial Genartion. 96 ${ }^{\text {th }}$ Annual Meeting of the Transportation Research Board

[25] Reeves, T. C. \& Oh, E., 2008. Generational Differences. In: Handbook of Research on Educational Communications. Springer, pp. 295-303

[26] Reicher, R. \& Kolnhofer Derecskei, A., 2018. Generációs különbségek a hétköznapi közlekedésben. /Generational differences in everyday transport. Siófok, Budapesti és Pest megyei Mérnöki Kamara, 7380

[27] Rive, G; \&Thomas, J; \& Jones, C; \& Frith, B; \& Chang, J., 2015. Public transport and the next generation June 2015, NZ Transport Agency research report

[28] Sándor Zs. P. \& Csiszár Cs., 2013. Development Stages of Intelligent Parking Information Systems for Trucks Acta Polytechnica Hungarica, pp: Vol. 10, No. 4, 2013

[29] Shearmur, R., 2016. The Millennial urban space-economy: dissolving workplaces and the de-localization of economic value creation, McGill School of Urban Planning: Working Paper 